Tersedia online di: http://ejournal-balitbang.kkp.go.id/index.php/JP
e-mail:jurnalpari@gmail.com
JURNAL PARI
Volume 4 Nomor 2 Desember 2018
p-ISSN: 2502-0730
e-ISSN : 2549-0133

\title{
JURNAL ELEKTRONIK BIDANG ILMU PERPUSTAKAAN SEBAGAI UPAYA MEMOBILISASI PENGETAHUAN ILMU PERPUSTAKAAN
}

\author{
Arief Wicaksono \\ Perpustakaan Nasional Republik Indonesia \\ Diterima tanggal : 12 September 2018 Diterima setelah perbaikan : 26 November 2018 \\ disetujui terbit : 8 November 2018
}

\begin{abstract}
ABSTRAK
Jurnal elektronik bidang ilmu perpustakaan merupakan sarana memobilisasi pengetahuan bidang ilmu perpustakaan. Hasil penelitian yang sudah ada membuktikan bahwa jurnal elektronik yang bersifat open source memang mampu memobilisasi pengetahuan yang berada di dalamnya. Pertanyaan yang ingin dijawab dalam penelitian ini adalah bagaimana kondisi jurnal elektronik bidang ilmu perpustakaan di Indonesia. Menjawab pertanyaan bagaimana kondisi jurnal elektronik bidang ilmu perpustakaan dapat menjadi gambaran umum pemobilisasian pengetahuan bidang ilmu perpustakaan. Penelitian ini dilakukan secara kuantitatif dengan mengambil data melalui penelusuran jurnal elektronik bidang ilmu perpustakaan, kunjungan ke website jurnal elektronik tersebut, dan pengambilan sampling untuk pencarian judul artikel yang terbit dalam jurnal elektronik untuk diterlusur di Indonesia OneSearch. Temuan penelitian adalah terdapat 25 jurnal elektronik yang sebagian besar diterbitkan oleh perguruan tinggi yang menyelenggarakan pendidikan ilmu perpustakaan. Secara umum jurnal elektronik tersebut terbit secara konsisten. Terdapat beberapa jurnal elektronik yang perlu diperhatikan karena terlihat baru terbit sampai tahun 2015 dan 2016 dan ada yang baru terbit di tahun 2017 saja. Ditemukan pula terdapat 9 jurnal elektronik yang tidak ditemukan dalam penelusuran judul artikel di Indonesia OneSeach.
\end{abstract}

Kata kunci: jurnal elektronik; open journal system; jurnal ilmu perpustakaan; Indonesia OneSearch; mobilisasi pengetahuan.

\begin{abstract}
Electronic journals in the field of library science are a means of mobilizing knowledge in the field of library science. Existing research results prove that electronic journals that are open source are indeed able to mobilize knowledge that is in it. The question to be answered in this study is how the condition of electronic journals in the field of library science in Indonesia. Answering the question of how the condition of the electronic journal in the field of library science can be a general description of the mobilization of knowledge in the field of library science. This research was conducted quantitatively by retrieving data through searching electronic journals in the field of library science, visits to the website of the electronic journal, and sampling for the search for the titles of articles published in electronic journals for publication in Indonesia OneSearch. The research findings are 25 electronic journals, most of which are published by universities that hold library science education. In general, the electronic journal published consistently. There are several electronic journals that need to be considered because they appear to have only been published until 2015 and 2016 and some have just been published in 2017. There were also found 9 electronic journals which were not found in the search for the title of the article in Indonesia OneSeach.
\end{abstract}

Keywords: electronic journal; open journal system; library science journal; Indonesia OneSearch; knowledge mobilization. 


\section{Latar Belakang}

Pengelola terbitan berkala atau jurnal ilmiah di Indonesia didorong untuk menerbitkan jurnal ilmiah secara elektronik. Peraturan Menteri Pendidikan Nasional Nomor 22 Tahun 2011 Tentang Terbitan Berkala IImiah menyatakan salah satu syarat jurnal ilmiah dapat diakreditasi adalah jurnal ilmiah tersebut diterbitkan secara tercetak dan secara elektronik melalui jejaring teknologi informasi dan komunikasi. Dorongan penerbitan jurnal ilmiah secara elektronik dikuatkan lagi melalui Surat Edaran Direktur Jenderal Pendidikan Tinggi Nomor 1223/E/T/2012 Tentang Kewajiban Penerbitan Terbitan Berkala IImiah Secara Elektronik yang menyatakan bahwa jurnal ilmiah yang akan diakreditasi selain diterbitkan secara tercetak diharuskan diterbitkan secara elektronik (online). Peraturan Kepala Lembaga IImu Pengetahuan Indonesia Nomor 3 Tahun 2014 dan Direktur Jenderal Pendidikan Tinggi Nomor 1 Tahun 2014 Tentang Pedoman Akreditasi Terbitan Berkala IImiah memperjelas dorongan penerbitan jurnal ilmiah elektronik.

Jurnal ilmiah yang diterbitkan secara elektronik dinilai mempunyai keuntungan mengurangi biaya percetakan dan memberikan akses yang lebih luas. Artikel yang terbit dalam jurnal elektronik memungkinkan artikel tersebut dapat diakses oleh pengguna internet secara terbuka dan tidak berbayar. Semangat yang dibangun melalui penerbitan jurnal ilmiah secara elektronik adalah semakin terbuka suatu artikel maka semakin besar kemungkinan artikel tersebut dapat diakses, semakin besar suatu artikel diakses maka pemanfaatan artikel tersebut baik sebagai dasar dari tulisan pemikiran dan/atau penelitan selanjutnya akan semakin besar pula. Dengan demikian, mobilisasi pengetahuan akan semakin dimudahkan melalui jurnal elektronik.

Jurnal ilmiah merupakan salah satu parameter bagi perkembangan ilmu pengetahuan yang diterbitkan sebuah institusi, baik institusi pendidikan maupun non-pendidikan. Bidang ilmu perpustakaan merupakan salah satu bidang ilmu yang terus berkembang. Perkembangan suatu bidang ilmu, termasuk ilmu perpustakaan, sangat terkait dengan pengembangan pemikiran dan penelitian dalam bidang tersebut. Pengembangan ilmu perpustakaan sangat membutuhkan dasar yang kuat untuk berpijak melalui pemikiran dan penelitian yang sudah ada, melalui melihat di atas bahu raksasa untuk menciptakan pengetahuan baru.

Perkembangan ilmu perpustakaan di Indonesia membutuhkan suatu cara yang disruptif dalam memobilisasi pengetahuan yang sudah ada. Penerbitan jurnal ilmiah bidang ilmu perpustakaan secara elektronik dinilai akan menjadi cara memobilisasi pengetahuan di bidang ilmu perpustakaan secara luas. Prasetyawan (2017) menyatakan diseminasi ilmu pengetahuan dapat diakselerasi melalui open access sehingga mampu memacu tumbuhnya ilmu pengetahuan baru. McKiernan dkk (2016) melalui tinjauan literatur atas banyak penelitian menemukan bahwa open research meningkatkan sitasi dan terbukti membawa keuntungan tersendiri bagi peneliti. Membuka akses untuk artikel dalam jurnal ilmiah ilmu perpustakaan seluas-luasnya akan memudahkan penemuan pemikiran dan penelitian yang sudah ada dalam bidang ilmu perpustakaan.

\section{Permasalahan}

Pengalaman dalam menelusur artikel ilmu perpustakaan di beberapa jurnal ilmiah bidang ilmu perpustakaan membangkitkan keingintahuan atas kondisi jurnal elektronik dalam bidang ilmu perpustakaan di Indonesia. Pertanyaan yang ingin dijawab melalui penelitian ini adalah:

a. Berapa banyak jurnal elektronik khusus bidang ilmu perpustakaan di Indonesia?

b. Bagaimana keterbaruan dari jurnal elektronik bidang ilmu perpustakaan di Indonesia?

c. Berapa banyak jurnal elektronik khusus bidang ilmu perpustakaan di Indonesia yang terindeks Indonesia OneSearch?

\section{Metode Penelitian}

Penelitian ini dilakukan dengan menggunakan metode analisis isi kuantitatif. Untuk mendapatkan jurnal elektronik di bidang ilmu perpustakaan dilakukan penelusuran melalui mesin pencari Google. Penelusuran dilakukan pada tanggal 23-30 Agustus 2018. Data keterbaruan jurnal elektronik dilihat dari volume yang telah terbit dengan mengunjungi website jurnal elektronik yang telah diidentifikasi. Data jurnal elektronik yang terindeks Indonesia OneSearch didapatkan dengan melakukan sampling pencarian judul di Indonesia OneSearch dari artikel yang ada di jurnal elektronik. Analisis data dilakukan dengan menambahkan pengalaman peneliti ketika berinteraksi dengan beberapa pengelola jurnal ilmiah elektronik di bidang ilmu perpustakaan dan didasarkan dari penelitian yang telah ada sebelumnya.

Keterbatasan penelitian ini adalah pengambilan data dengan waktu yang sempit sehingga menjadikan kemungkinan ada jurnal elektronik khusus bidang ilmu perpustakaan yang tidak ditemukan. Selain itu, 
penelitian ini tidak melakukan konfirmasi kepada instansi yang menerbitkan jurnal elektronik dan tidak menanyakan langsung kepada instansi yang mungkin menerbitkan jurnal elektronik. Pengambilan data hanya didasarkan pada temuan dari hasil penelusuran melalui mesin pencari Google mengingat jurnal elekronik yang menggunakan aplikasi Open Journal System terindeks dengan baik di Google.

\section{Jurnal Elektronik}

Dari sisi keterbukaan akses, jurnal elektronik terbagi menjadi dua yaitu closed access dan open access (Azwar dan Amaliah, 2017). Jurnal elektronik closed access adalah database online yang memuat informasi ilmiah berupa buku dan jurnal elektronik. Jurnal elektronik ini tidak dapat diakses bila tidak melanggannya dan menggunakan password untuk mengaksesnya. Jurnal elektronik open access adalah jurnal yang memungkinkan pengguna untuk mengkases secara gratis. Siapapun di seluruh dunia dapat mengkasesnya tanpa hambatan baik dalam masalah legal maupun teknis jurnal elektronik yang tersedia secara online dan terbuka ini.

Open Journal System (OJS) merupakan salah satu perangkat aplikasi yang populer digunakan untuk mengelola jurnal secara online (Arief dan Handoko, 2016). Alasan kepopuleran OJS adalah OJS bersifat open source atau gratis, memiliki fitur yang mumpuni untuk menangani publikasi online, dan terhubung dengan berbagai mesin pencari (search engine) sehingga memudahkan indentifikasi dan pencarian artikel. Fitur penanganan publikasi online pada OJS adalah fitur pengelolaan penerbitan, pengelolaan editing online, pengelolaan user dengan berbagai level user, tampilan yang sederhana dan user friendly, serta fitur untuk membaca jurnal secara online.

OJS merupakan salah satu produk open source dari PKP (Public Knowlegde Project) yang khusus digunakan untuk mengelola jurnal online. Karena bersifat open source dengan lisensi GPL (General Public License), maka software ini dapat digunakan oleh siapa saja untuk belajar, meneliti, dan mengubahnya. Aplikasi ini sangat kompatibel dengan mesin pencari Google begitu juga Google Scholarnya sehingga artikel yang dimuat pada jurnal online yang memakai OJS akan terindeks oleh Google lebih baik.

Nashihuddin dan Aulianto (2016) menjelaskan dengan gamblang bagaimana pengelolaan jurnal ilmiah sesuai dengan ketentuan akreditasi yang diatur dalam Peraturan Kepala Lembaga IImu Pengetahuan Indonesia Nomor 3 Tahun 2014 dan Direktur Jenderal
Pendidikan Tinggi Nomor 1 Tahun 2014. Disebutkan bahwa data terbitan jurnal ilmiah yang diakreditasi oleh Lembaga Ilmu Pengetahuan Indonesia sebanyak 190 jurnal dan yang diakreditasi oleh Direktur Jenderal Pendidikan Tinggi sebanyak 172 jurnal. Menurut Nashihuddin dan Aulianto (2016), OJS ditetapkan sebagai standar sistem aplikasi jurnal elektronik.

Penelitian terdahulu terkait OJS dan perpustakaan ditemukan dilakukan Elnumeri dan Nashihuddin (2017). Penelitian dilakukan dari sudut pustakawan sebagai pengelola jurnal ilmiah kepustakawanan dimana ditemukan ternyata banyak pustakawan yang terlibat dalam pengelolaan jurnal ilmiah. Penelitian terkait jurnal ilmiah di bidang ilmu perpustakaan dilakukan oleh Purnomowati (2001). Dinyatakan bahwa majalah bidang ilmu perpustakaan dan informasi yang terbit saat ini sudah berfungsi sebagai sarana komunikasi dian tara para pengelolainformasi dan masyarakat pemakainya, tetapi belum optimal dalam mengemban fungsinya sebagai sarana komunikasi ilmiah untuk mendukung kemajuan ilmu perpustakaan dan informasi.

\section{Hasil Penelitian}

Ditemukan 25 jurnal elektronik khusus bidang ilmu perpustakaan. Jurnal elektronik tersebut terdiri atas 21 jurnal elektronik yang diterbitkan oleh perguruan tinggi dan 4 jurnal yang diterbitkan oleh lembaga bukan perguruan tinggi (4 jurnal). Sebagian besar perguruan tinggi yang ditemukan menerbitkan jurnal elektronik adalah perguruan tinggi di Pulau Jawa, yaitu 12 jurnal. Perguruan tinggi yang di luar pulau Jawa yang menerbitkan jurnal elektronik adalah Bali (1 jurnal), Sumatera (4 jurnal), Kalimantan (1 jurnal) dan Sulawesi (3 jurnal).

Jurnal yang ditemukan diterbitkan bukan dari lingkungan perguruan tinggi berjumlah 4 jurnal. Jurnal tersebut adalah jurnal BACA yang diterbitkan oleh Pusat Dokumentasi dan Informasi IImiah-Lembaga IImu Pengetahuan Indonesia (PDII-LIPI), Jurnal Perpustakaan Pertanian yang diterbitkan oleh Pusat Perpustakaan dan Penyebaran Teknologi Pertanian, Jurnal Ikatan Pustakawan Indonesia yang diterbitkan oleh Ikatan Pustakawan Indonesia (IPI), dan Journal of Documentation and Information Science yang diterbitkan oleh Ikatan Sarjana IImu Perpustakaan dan Informasi Indonesia (ISIPII).

Perpustakaan Nasional RI ditemukan mengonlinekan dua majalah ilmiahnya, yaitu Media Pustakawan yang diterbitkan oleh Pusat Pengembangan Pustakawan di alamat http:// pustakawan.perpusnas.go.id/media dan Visi Pustaka 
yang diterbitkan oleh Pusat Jasa Perpustakaan dan Informasi di alamat http://www.pnri.go.id/ magazine.php?lang=id\&id=Visi\%20Pustaka namun tidak menggunakan OJS. Perpustakaan Nasional RI hanya menggunggah majalah ilmiahnya ke website dan tidak ada manajamen pengelolaan jurnal secara online seperti ketika menggunakan OJS. Oleh karena alasan ini, majalah ilmiah terbitan Perpustakaan Nasional RI tidak dimasukkan.

Tabel 1. OJS Bidang IImu Perpustakaan

\begin{tabular}{|c|c|c|c|}
\hline No & Jurnal & Penerbit & URL \\
\hline 1 & Jurnal IImiah D3 Perpustakaan & $\begin{array}{l}\text { FISIP Universitas } \\
\text { Udayana }\end{array}$ & $\begin{array}{l}\text { https://ojs.unud.ac.id/index.php/ } \\
\text { d3perpus/index }\end{array}$ \\
\hline 2 & Libraria: jurnal perpustakaan & $\begin{array}{l}\text { UPT Perpustakaan STAIN } \\
\text { Kudus }\end{array}$ & $\begin{array}{l}\text { http://journal.stainkudus.ac.id/in } \\
\text { dex.php/Libraria/index }\end{array}$ \\
\hline 3 & $\begin{array}{l}\text { Jurnal Ilmu Informasi, } \\
\text { Perpustakaan, dan Kearsipan }\end{array}$ & $\begin{array}{l}\text { Departemen Ilmu } \\
\text { Perpustakaan dan } \\
\text { Informasi, FIB UI }\end{array}$ & http://jipk.ui.ac.id/index.php/jipk \\
\hline 4 & $\begin{array}{l}\text { Al Maktabah: jurnal komunikasi } \\
\text { dan informasi perpustakaan }\end{array}$ & $\begin{array}{l}\text { Perpustakaan Pusat UIN } \\
\text { Syarif Hidayatullah } \\
\text { Jakarta }\end{array}$ & $\begin{array}{l}\text { http://journal.uinjkt.ac.id/index.p } \\
\text { hp/al-maktabah }\end{array}$ \\
\hline 5 & $\begin{array}{l}\text { Berkala IImu Perpustakaan dan } \\
\text { Informasi }\end{array}$ & $\begin{array}{l}\text { Perpustakaan Universitas } \\
\text { Gadjah Mada }\end{array}$ & https://jurnal.ugm.ac.id/bip \\
\hline 6 & $\begin{array}{l}\text { Jurnal Kajian Informasi dan } \\
\text { Perpustakaan }\end{array}$ & $\begin{array}{l}\text { Program Studi Ilmu } \\
\text { Perpustakaan Universitas } \\
\text { Padjajaran }\end{array}$ & http://jurnal.unpad.ac.id/jkip \\
\hline 7 & $\begin{array}{l}\text { Pustakaloka: Jurnal Kajian } \\
\text { Informasi dan Perpustakaan }\end{array}$ & STAIN Ponorogo & $\begin{array}{l}\text { http://jurnal.stainponorogo.ac.id/i } \\
\text { ndex.php/pustakaloka/index }\end{array}$ \\
\hline 8 & $\begin{array}{l}\text { Al Kuttab: Jurnal Perpustakaan } \\
\text { dan Informasi }\end{array}$ & $\begin{array}{l}\text { UPT Perpustakaan Pusat } \\
\text { IAIN Padangsidimpuan }\end{array}$ & $\begin{array}{l}\frac{\text { http://jurnal.iain- }}{\text { padangsidimpuan.ac.id/index.ph }} \\
\text { p/alkuttab/index }\end{array}$ \\
\hline 9 & $\begin{array}{l}\text { Jurnal IImu Informasi } \\
\text { Perpustakaan dan Kearsipan }\end{array}$ & $\begin{array}{l}\text { Program Studi Ilmu } \\
\text { Informasi Perpustakaan } \\
\text { dan Kearsipan, } \\
\text { Universitas Negeri } \\
\text { Padang }\end{array}$ & $\begin{array}{l}\text { http://ejournal.unp.ac.id/index.ph } \\
\text { p/iipk/index }\end{array}$ \\
\hline 10 & $\begin{array}{l}\text { Bibliotika: Jurnal Kajian } \\
\text { Perpustakaan dan Informasi }\end{array}$ & $\begin{array}{l}\text { Program Studi Ilmu } \\
\text { Perpustakaan Universitas } \\
\text { Negeri Malang }\end{array}$ & $\begin{array}{l}\text { http://journal2.um.ac.id/index.ph } \\
\text { p/bibliotika }\end{array}$ \\
\hline 11 & Record and Library Journal & Universitas Airlangga & $\frac{\text { https://e- }}{\text { journal.unair.ac.id/RLJ/index }}$ \\
\hline 12 & $\begin{array}{l}\text { Edulib: Journal Library and } \\
\text { Information Science }\end{array}$ & $\begin{array}{l}\text { Univesitas Pendidikan } \\
\text { Indonesia }\end{array}$ & $\begin{array}{l}\text { http://ejournal.upi.edu/index.php } \\
\underline{\text { ledulib }}\end{array}$ \\
\hline 13 & Jurnal Pustakawan Indonesia & Institut Pertanian Bogor & $\begin{array}{l}\text { http://journal.ipb.ac.id/index.php/ } \\
\text { ipi/index }\end{array}$ \\
\hline 14 & Buletin Perpustakaan & $\begin{array}{l}\text { Universitas Islam } \\
\text { Indonesia }\end{array}$ & http://journal.uii.ac.id/Buletin- \\
\hline 15 & $\begin{array}{l}\text { Lentera Pustaka: Jurnal Kajian } \\
\text { Ilmu Perpustakaan, Informasi, } \\
\text { dan Kearsipan }\end{array}$ & $\begin{array}{l}\text { Program Studi Ilmu } \\
\text { Perpustakaan Universitas } \\
\text { Diponegoro }\end{array}$ & $\begin{array}{l}\text { https://ejournal.undip.ac.id/index } \\
\text {.php/lpustaka }\end{array}$ \\
\hline 16 & $\begin{array}{l}\text { JIPI (Jurnal IImu Perpustakaan } \\
\text { dan Informasi) }\end{array}$ & $\begin{array}{l}\text { Program Studi Ilmu } \\
\text { Perpustakaan Fakultas } \\
\text { Ilmu Sosial UIN Sumatera } \\
\text { Utara }\end{array}$ & $\begin{array}{l}\text { http://jurnal.uinsu.ac.id/index.ph } \\
\text { p//ipi/index }\end{array}$ \\
\hline 17 & $\begin{array}{l}\text { Iqra': Jurnal Perpustakaan dan } \\
\text { Informasi }\end{array}$ & $\begin{array}{l}\text { Perpustakaan UIN } \\
\text { Sumatera Utara }\end{array}$ & $\begin{array}{l}\text { http://jurnal.uinsu.ac.id/index.ph } \\
\text { p/iqra }\end{array}$ \\
\hline 18 & Libria: Library of UIN Ar-Raniry & UIN Ar Raniry & $\begin{array}{l}\text { https://jurnal.ar- } \\
\text { raniry.ac.id/index.php/libria }\end{array}$ \\
\hline 19 & $\begin{array}{l}\text { Khizanah Al Hikmah: Jurnal } \\
\text { Ilmu Perpustakaan, Information, } \\
\text { dan Kearsipan }\end{array}$ & UIN Alauddin Makassar & $\begin{array}{l}\text { http://journal.uin- } \\
\text { alauddin.ac.id/index.php/khizan } \\
\text { ah-al-hikmah/index }\end{array}$ \\
\hline
\end{tabular}




\begin{tabular}{|c|c|c|c|}
\hline 20 & $\begin{array}{l}\text { Jupiter: Jurnal Bidang } \\
\text { Kepustakawanan, Dokumentasi } \\
\text { Informasi dan Komputerisasi } \\
\text { Perpustakaan }\end{array}$ & Universitas Hassanudin & $\begin{array}{l}\text { http://journal.unhas.ac.id/index.p } \\
\text { hp/jupiter/index }\end{array}$ \\
\hline 21 & Pustaka Karya & $\begin{array}{l}\text { IAIN Antasari } \\
\text { Banjarmasin }\end{array}$ & $\begin{array}{l}\text { http://jurnal.uin- } \\
\text { antasari.ac.id/index.php/pustaka } \\
\text { karya }\end{array}$ \\
\hline 22 & Jurnal Perpustakaan Pertanian & $\begin{array}{l}\text { Pusat Perpustakaan dan } \\
\text { Penyebaran Teknologi } \\
\text { Pertanian }\end{array}$ & http://ejurnal.litbang.pertanian.g \\
\hline 23 & $\begin{array}{l}\text { BACA: Jurnal Dokumentasi dan } \\
\text { Informasi }\end{array}$ & PDII-LIPI & $\begin{array}{l}\text { http://jurnalbaca.pdii.lipi.go.id/ind } \\
\text { ex.php/baca }\end{array}$ \\
\hline 24 & $\begin{array}{l}\text { Jurnal Ikatan Pustakawan } \\
\text { Indonesia }\end{array}$ & IPI & $\begin{array}{l}\text { http://www.ipi.web.id/jurnal/index } \\
\text {.php/jurnalipi }\end{array}$ \\
\hline 25 & $\begin{array}{l}\text { Journal of Documentation and } \\
\text { Information Science }\end{array}$ & ISIPII & $\begin{array}{l}\text { http://jodis.isipii.org/index.php/jo } \\
\text { dis }\end{array}$ \\
\hline
\end{tabular}

Jurnal elektronik bidang ilmu perpustakaan yang ditemukan terbit sampai dengan tahun 2018 berjumlah 15 jurnal. Ditemukan 9 jurnal yang belum menerbitkan volumenya di tahun 2018 , satu jurnal diantaranya terakhir terbit di tahun 2015, satu jurnal terakhir terbit di tahun 2016, dan tiga jurnal terakhir terbit di tahun 2017. Dua jurnal yang terakhir terbit di tahun 2017 adalah jurnal elektronik yang baru mulai terbit juga di tahun 2017.

Tabel 2. Masa Hidup OJS Bidang IImu Perpustakaan

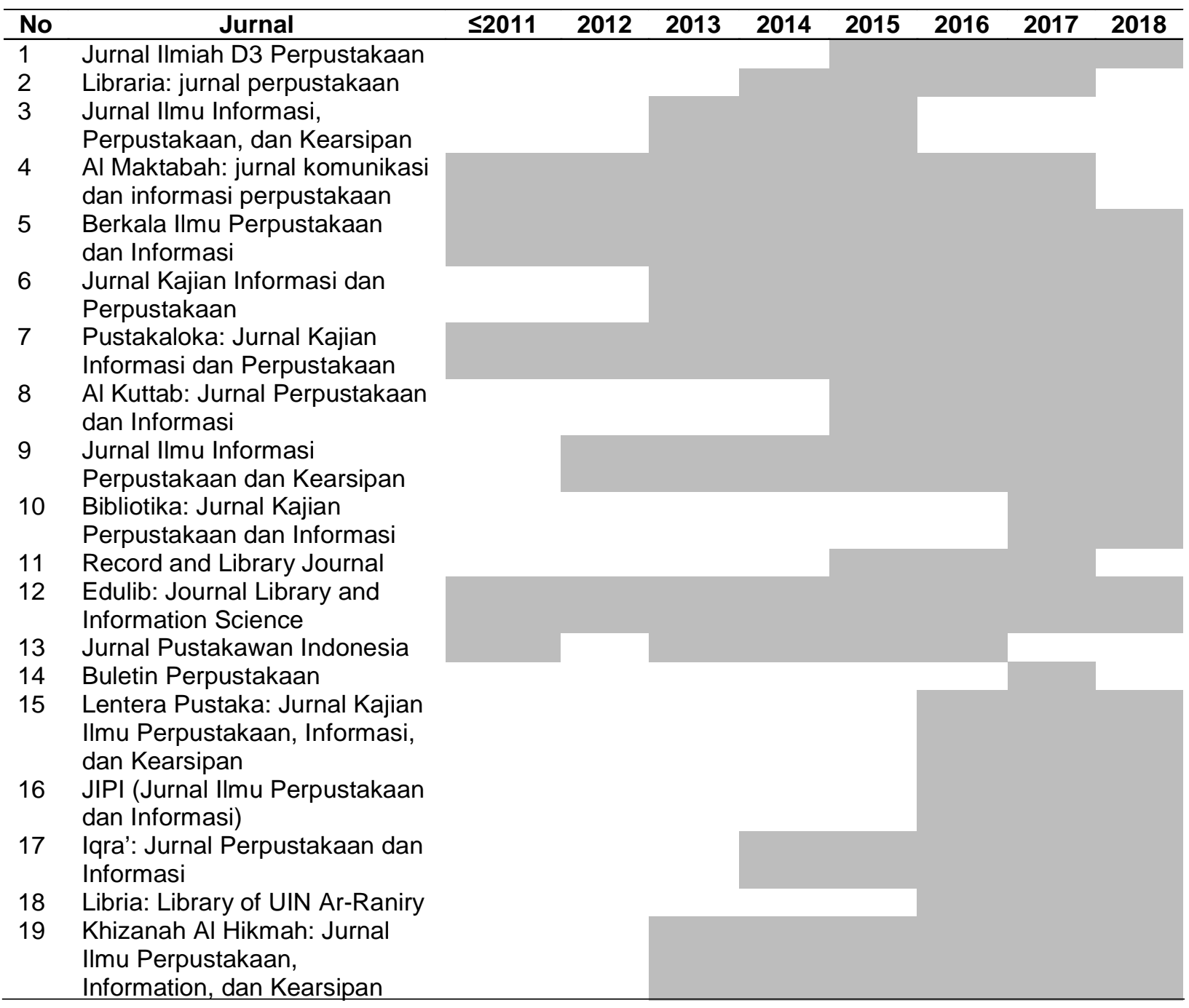




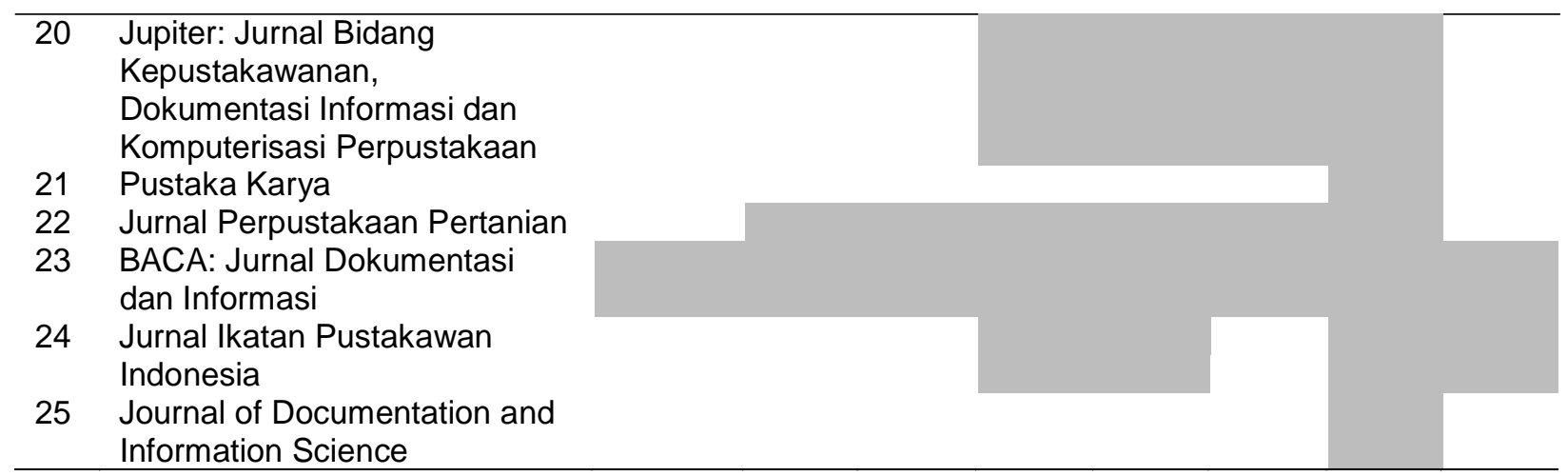

Jurnal ilmiah yang ditemukan sudah menggunggah jurnal secara elektronik yang terbit dibawah dan sama dengan tahun 2011 sebanyak 6 jurnal, yaitu Edulib mulai dari 2011, Pustakaloka mulai dari tahun 2009, Al Maktabah mulai dari tahun 1999, Jurnal Pustakawan Indonesia mulai dari tahun 1997, dan Jurnal BACA mulai dari tahun 1986. Jurnal ilmiah elektronik yang terbit setelah tahun 2011 berjumlah 19 jurnal. Dua jurnal mulai terbit di tahun 2012, empat jurnal mulai terbit di tahun 2013, tiga jurnal mulai terbit di tahun 2014, tiga jurnal mulai terbit di tahun 2015, tiga jurnal mulai terbit di tahun 2016, dan tiga jurnal mulai terbit di tahun 2017.

Tabel 3. Frekuensi Terbit OJS Bidang IImu Perpustakaan

\begin{tabular}{|c|c|c|}
\hline No & Jurnal & Volume \\
\hline 1 & Jurnal IImiah D3 Perpustakaan & 2015-2018: @1x terbit \\
\hline 2 & Libraria: jurnal perpustakaan & $\begin{array}{l}\text { 2014-2016: @2x terbit } \\
\text { 2017: 1x terbit }\end{array}$ \\
\hline 3 & $\begin{array}{l}\text { Jurnal IImu Informasi, Perpustakaan, } \\
\text { dan Kearsipan* }\end{array}$ & $\begin{array}{l}\text { 2013-2014: @1x terbit } \\
\text { 2015: } 2 x \text { terbit }\end{array}$ \\
\hline 4 & $\begin{array}{l}\text { Al Maktabah: jurnal komunikasi dan } \\
\text { informasi perpustakaan }\end{array}$ & $\begin{array}{l}\text { 1999: } 1 x \text { terbit } \\
\text { 2000-2001: @2x terbit } \\
\text { 2002, 2004, 2006-2007, 2010, 2012-2017: @1x terbit }\end{array}$ \\
\hline 5 & $\begin{array}{l}\text { Berkala Ilmu Perpustakaan dan } \\
\text { Informasi }\end{array}$ & $\begin{array}{l}\text { 2005-2006: @1x terbit } \\
\text { 2007-2017: @2x terbit } \\
\text { 2018: } 1 x \text { terbit }\end{array}$ \\
\hline 6 & $\begin{array}{l}\text { Jurnal Kajian Informasi dan } \\
\text { Perpustakaan }\end{array}$ & $\begin{array}{l}\text { 2013-2017: @2x terbit } \\
\text { 2018: 1x terbit }\end{array}$ \\
\hline 7 & $\begin{array}{l}\text { Pustakaloka: Jurnal Kajian Informasi } \\
\text { dan Perpustakaan }\end{array}$ & $\begin{array}{l}\text { 2009-2015: @1x terbit } \\
\text { 2016-2017: @2x terbit } \\
\text { 2018: 1x terbit }\end{array}$ \\
\hline 8 & $\begin{array}{l}\text { Al Kuttab: Jurnal Perpustakaan dan } \\
\text { Informasi }\end{array}$ & 2015-2018: @1x terbit \\
\hline 9 & $\begin{array}{l}\text { Jurnal Ilmu Informasi Perpustakaan } \\
\text { dan Kearsipan }\end{array}$ & $\begin{array}{l}\text { 2012: 1x terbit } \\
\text { 2013-2014: @2x terbit } \\
\text { 2015-2016: @1x terbit } \\
\text { 2017-2018: @2x terbit }\end{array}$ \\
\hline 10 & $\begin{array}{l}\text { Bibliotika: Jurnal Kajian Perpustakaan } \\
\text { dan Informasi }\end{array}$ & $\begin{array}{l}\text { 2017: } 2 x \text { terbit } \\
\text { 2018: } 1 \times \text { terbit }\end{array}$ \\
\hline 11 & Record and Library Journal & 2015-2017: @2x terbit \\
\hline 12 & $\begin{array}{l}\text { Edulib: Journal Library and Information } \\
\text { Science }\end{array}$ & $\begin{array}{l}\text { 2011: } 1 x \text { terbit } \\
\text { 2012-2017: @2x terbit } \\
\text { 2018: } 1 x \text { terbit }\end{array}$ \\
\hline 13 & Jurnal Pustakawan Indonesia & $\begin{array}{l}\text { 1997: } 1 x \text { terbit } \\
\text { 1998: 2x terbit } \\
\text { 1999, 2004-2007: @1x terbit } \\
\text { 2010-2011, 2013-2015: @2x terbit } \\
\text { 2016: 1x terbit }\end{array}$ \\
\hline 14 & Buletin Perpustakaan & 2017: $2 x$ terbit \\
\hline
\end{tabular}




\begin{tabular}{|c|c|c|}
\hline 15 & $\begin{array}{l}\text { Lentera Pustaka: Jurnal Kajian IImu } \\
\text { Perpustakaan, Informasi, dan } \\
\text { Kearsipan }\end{array}$ & $\begin{array}{l}\text { 2016-2017: @2x terbit } \\
\text { 2018: 1x terbit }\end{array}$ \\
\hline 16 & $\begin{array}{l}\text { JIPI (Jurnal IImu Perpustakaan dan } \\
\text { Informasi) }\end{array}$ & $\begin{array}{l}\text { 2016: } 2 x \text { terbit } \\
\text { 2017: } 2 x \text { terbit } \\
\text { 2018: } 2 x \text { terbit }\end{array}$ \\
\hline 17 & $\begin{array}{l}\text { Iqra': Jurnal Perpustakaan dan } \\
\text { Informasi }\end{array}$ & $\begin{array}{l}\text { 2014: } 1 x \text { terbit } \\
\text { 2015-2017: @2x terbit } \\
\text { 2018: } 1 x \text { terbit }\end{array}$ \\
\hline 18 & Libria: Library of UIN Ar-Raniry & 2016-2017: @2x terbit \\
\hline 19 & $\begin{array}{l}\text { Khizanah Al Hikmah: Jurnal Ilmu } \\
\text { Perpustakaan, Information, dan } \\
\text { Kearsipan }\end{array}$ & $\begin{array}{l}\text { 2013-2017: @2x terbit } \\
\text { 2018: 1x terbit }\end{array}$ \\
\hline 20 & $\begin{array}{l}\text { Jupiter: Jurnal Bidang } \\
\text { Kepustakawanan, Dokumentasi } \\
\text { Informasi dan Komputerisasi } \\
\text { Perpustakaan }\end{array}$ & 2014-2017: @2x terbit \\
\hline 21 & Pustaka Karya & 2017: $1 x$ terbit \\
\hline 22 & Jurnal Perpustakaan Pertanian & 2012-2017: @2x terbit \\
\hline 23 & $\begin{array}{l}\text { BACA: Jurnal Dokumentasi dan } \\
\text { Informasi }\end{array}$ & $\begin{array}{l}\text { 1986-1989: @2x terbit } \\
\text { 1990: 4x terbit } \\
\text { 1991: 1x terbit } \\
\text { 1992: 3x terbit } \\
\text { 1993: 2x terbit } \\
\text { 1994: 3x terbit } \\
\text { 1995-1996: @4x terbit } \\
\text { 1997-1998: @3x terbit } \\
\text { 1999-2000: @2x terbit } \\
\text { 2001: 1x terbit } \\
\text { 2003-2004: @2x terbit } \\
\text { 2005: 1x terbit } \\
\text { 2009-2017: @2x terbit } \\
\text { 2018: @1x terbit }\end{array}$ \\
\hline 24 & Jurnal Ikatan Pustakawan Indonesia & 2014-2015 dan 2016-2017: @1x terbit \\
\hline 25 & $\begin{array}{l}\text { Journal of Documentation and } \\
\text { Information Science }\end{array}$ & 2017: $1 x$ terbit \\
\hline
\end{tabular}

Secara umum, jurnal elektronik khusus bidang ilmu perpustakaan yang ditemukan konsen untuk terus menerbitkan volume terbitan setiap tahunnya. Jurnal elektronik khusus bidang ilmu perpustakaan yang terlihat konsen untuk terus menerbitkan volumenya setiap tahun adalah jurnal BACA. Jurnal BACA menggunggah terbitannya mulai tahun 1986 dan terus terbit sampai dengan tahun 2018 dengan telah menerbitkan satu nomor di tahun 2018. Meskipun ada tahun 2002, 2006 sampai dengan tahun 2008 yang kehilatan tidak ada di website jurnal elektronik BACA. PDII-LIPI yang menerbitkan Jurnal BACA mungkin saja terdorong untuk memberikan contoh yang baik karena PDII-LIPI juga yang menerbitkan ISSN.

Jurnal Berkala IImu Perpustakaan dan Informasi yang diterbitkan Universitas Gadjah Mada juga terlihat konsen dengan mengunggah terbitannya mulai tahun 2005 dan terus terbit sampai dengan tahun 2018 dengan telah menerbitkan satu nomor di tahun 2018. Pustakaloka yang diterbitkan oleh STAIN Ponorogo mirip dengan Jurnal Berkala hanya saja mulai mengunggah terbitannya pada tahun 2009, Edulib yang diterbitkan Universitas Pendidikan Indonesia yang baru mulai mengunggah terbitannya pada tahun 2011, dan Pustaka Karya yang diterbitkan Universitas Negeri padang yang baru mengunggah terbitannya pada tahun 2012.

Dari sekian jurnal yang terdata di atas terdapat tiga jurnal elektronik yang patut diberikan perhatian, yaitu Buletin Perpustakaan yang diterbitkan Universitas Islam Indonesia, Pustaka Karya yang diterbitkan IAIN Antasari Banjarmasin, dan Journal of Documentation and Information Science yang diterbitkan oleh Ikatan Sarjana IImu Perpustakaan dan Informasi Indonesia. Ketiga jurnal ini baru terbit di tahun 2017 dan belum menerbitkan volumenya di tahun 2018 . Selain itu juga terdapat dua jurnal yang juga patut 
diberikan perhatian, yaitu Jurnal IImu Informasi, Perpustakaan, dan Kearsipan yang diterbitkan oleh Universitas Indonesia yang terakhir terbit di tahun 2015 untuk dan Jurnal Pustakawan Indonesia yang diterbitkan Institut Pertanian Bogor yang terakhir terbit di tahun 2016.

Data selanjutnya adalah dikaitkan dengan Indonesia OneSearch yang dikembangkan Perpustakaan Nasional RI. Dari hasil sampling pencarian judul artikel yang didapatkan dari dua lima jurnal di atas ditemukan sembilan jurnal yang tidak terindeks Indonesia OneSearch. Indonesia OneSearch yang merupakan satu pintu untuk pencarian untuk semua koleksi publik dari perpustakaan, museum, arsip, dan sumber elektronik di Indonesia perlu terus mengajak mitra Indonesia OneSearch untuk bergabung.

\section{Pembahasan}

Ditemukan 25 jurnal elektronik khusus bidang ilmu perpustakaan yang diterbitkan oleh perguruan tinggi dan non perguruan tinggi. Jika dilihat lebih dalam ternyata 25 jurnal elektronik tersebut diterbitkan oleh 24 lembaga karena ditemukan Universitas Sumatera Utara menerbitkan dua jurnal yaitu satu jurnal diterbitkan oleh program studi ilmu perpustakaan dan satu jurnal lagi diterbitkan oleh perpustakaan pusat. Jumlah ini terlihat masih sangat kecil dibandingkan dengan jumlah jurnal elektronik yang ada dari berbagai bidang yang berdasarkan data berjumlah 21.820 jurnal.

\section{Perkembangan Jurnal Elektronik} Nasional 2013-2017

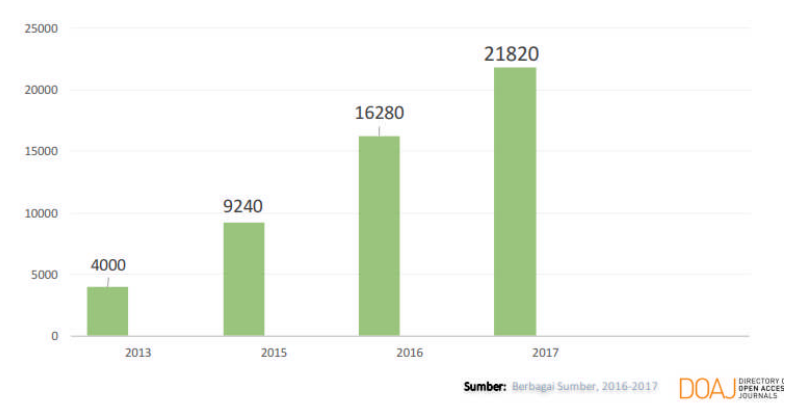

Gambar 1.Perkembangan Jurnal Elektronik Indonesia

(Sumber: http://sinta2.ristekdikti.go.id/assets/files/ Presentasi_Menristek_Sinta2.pdf)

Nashihuddin (2014) menemukan sebanyak 32 perguruan tinggi yang menyelengarakan pendidikan ilmu perpustakaan di Indonesia. Ditemukan 21 perguruan tinggi yang menyelenggarakan pendidikan ilmu perpustakaan di Indonesia menerbitkan jurnal khusus bidang ilmu perpustakaan. Melihat jumlah tersebut terlihat lebih dari separuh perguruan tinggi yang menyelenggarakan pendidikan ilmu perpustakaan menerbitkan jurnal elektronik khusus bidang ilmu perpustakaan.

Diluar dari 21 perguruan tinggi di atas, ditemukan ada program studi ilmu perpustakaan di perguruan tinggi yang mempunyai jurnal elektronik namun tidak bisa diakses tautannya, yaitu Shaut al-Maktabah (http://ejournal.uinib.ac.id/index.php?journal=SM) yang diterbitkan oleh Universitas Islam Negeri Imam Bonjol Padang. Ditemukan jurnal elektronik bidang ilmu perpustakaan dan tautannya berfungsi dengan baik namun belum ada terbitan yang diunggah, yaitu Jurnal FIHRIS: Jurnal Bidang Kajian Perpustakaan yang diterbitkan UIN Sunan Kalijaga (http:// ejournal.uin-suka.ac.id/adab/FIHRIS/index) juga ditemukan sama.

Ditemukan ada program studi ilmu perpustakaan yang mempunyai jurnal namun tidak khusus bidang ilmu perpustakaan. Program studi tersebut menginduk jurnal yang diterbitkan oleh fakultas dimana program studi perpustakaan menginduk. Perpustakaan Univrersitas Muhammadiyah Mataram terlihat mempunyai jurnal namun diterbitkan bersama oleh Fakultas IImu Sosial dan Politik, yaitu jurnal Transformasi.Tertulis dalam websitenya (http:// journal.ummat.ac.id/index.php/transformasi) bahwa redaksi menerima naskah artikel penelitian sesuai dengan scope dari jurnal yakni, studi IImu Pemerintah, Administrasi Publik, Administrasi Bisnis, dan Perpustakaan. Setelah dikunjungi website tersebut belum ada jurnal yang diunggah.

Beberapa program studi ilmu perpustakaan ditemukan juga memiliki jurnal yang menginduk ke fakultas atau jurusan dimana program studi atau konsentrasi ilmu perpustakaan bernaung namun jurnal tersebut dapat diakses dan telah ada terbitan elektroniknya. Salah satunya adalah Jurnal IImu Komunikasi dan Informasi (http://ojs.uho.ac.id/ index.php/KOMUNIKASI/index) yang diterbitkan Fakultas IImu Sosial dan IImu Politik Universitas Haluoleo. Contoh jurnal lainnya adalah Jurnal Acta Diurna (https://ejournal.unsrat.ac.id/index.php/ actadiurna/index ) yang diterbitkan Jurusan IImu Komunikasi Fispol Universita Sam Ratulangi.

Data yang telah diungkap dalam penelitian ini mengisyaratkan penyelenggara pendidikan perpustakaan masih harus terus mengembangkan diri melalui penerbitan jurnal ilmiah elektronik sebagai sarana komunikasi dan mobilisasi pengetahuan dalam bidang ilmu perpustakaan. Jurnal ilmiah yang diterbitkan menjadi salah satu bukti pengembangan 
ilmu yang dilakukan sebagai tuntutan dari Tri Darma Perguruan Tinggi. Data ini dapat menjadi alasan kenapa perkembangan ilmu perpustakaan di Indonesia masih belum banyak terlihat, yaitu dari segi pemikiran dan penelitian yang belum banyak. Bahkan secara informal beberapa pengelola jurnal elektronik khusus bidang ilmu perpustakaan menyatakan kesulitan untuk mencari artikel untuk diterbitkan. Iskak (2016) menyatakan bahwa Jurnal Perpustakaan Pertanian selalu mengalami kekurangan naskah karena minimnya kontribusi artikel dari pustakawan.

Para pustakawan, dosen ilmu perpustakaan, mahasiswa perpustakaan, dan peneliti di bidang perpustakaan juga perlu terus melakukan pengkajian atas bidang ilmu perpustakaan. Misalnya, dalam birokrasi pustakawan di pemerintahan terdapat unsur kegiatan berupa penulisan karya ilmiah yang dapat dinilai dan mendapatkan kredit. Jurnal elektronik di bidang ilmu perpustakaan dapat menjadi sarana penyaluran atas karya ilmiah yang telah dibuat. Rutinitas dalam melakukan pekerjaan sehari-hari jangan sampai menjadi alasan untuk tidak melakukan pengembangan keilmuwan. Beberapa penelitian telah menemukan rendahnya karya ilmiah dari pustakawan. Iskak (2016) menyatakan pengkajian yang dilakukan pustakawan masih minim dan hal ini menjadi salah satu penyebab rendahnya kontribusi artikel dalam jurnal ilmiah bidang ilmu perpustakaan. Penelitian lain yang dilakukan Laksmi dan Wijayanti (2012) menyimpulkan bahwa sejak tahun 2000 -an riset dalam ilmu perpustakaan dan informasi di Indonesia berkembang secara lambat. Pelaku riset yang diidentifikasi Laksmi dan Wijayanti tidak hanya pustakawan tetapi juga termasuk mahasiswa dan pengajar atau dosen.

\section{Penutup}

Mobilisisasi pengetahuan bidang ilmu perpustakaan dapat dilakukan melalui jurnal elektronik yang diterbitkan perguruan tinggi dan non-perguruan tinggi dan dengan terindeksnya jurnal elektronik bidang ilmu pengetahuan di Indonesia OneSearch. Kuantitas dan kualitas mobilisasi pengetahuan perlu dipertahankan dan ditingkatkan melalui budaya pengembangan pemikiran dan pelaksanaan penelitian yang dituangkan dalam tulisan ilmiah oleh pustakawan, serta dosen, peneliti, dan mahasiswa ilmu perpustakaanyang diterbitkan ke dalam jurnal elektronik.

\section{Referensi}

Arief, I. \& Handoko. 2016. Jurnal Online dengan Open Journal System. Medan: Lembaga Pengembangan Teknologi Informasi dan Komunikasi Universitas Andalas. Diakses tanggal 28 Agustus $2018 \mathrm{di}$ http://repo.unand.ac.id/4029/ $1 / \mathrm{Fixed} \% 20 \mathrm{Jurnal} \% 200 \mathrm{nline} \% 20$ dengan\%200JS.pdf.

Azwar, M. \& Amaliah, R. 2017. Pemanfaatan jurnal elektronik sebagai sumber referensi dalam penulisan skripsi di Institut Pertanian Bogor. Libraria, 5(1): 1-24.

Elnumeri, F. \& Nashihuddin, W. 2017. Keterlibatan pustakawan dalam pengelolaan jurnal ilmiah elektronik lembaga. Jurnal Ikatan Pustakawan Indonesia, 2(1): 78-94.

Iskak, P.I. 2016. Faktor penghambat pustakawan lingkup Kementerian Pertanian dalam pengkajian perpustakaan dan informasi. Jurnal Perpustakaan Pertanian, 24 (1): 8-16.

Laksmi, \& Wijayanti, L. 2012. Indonesian Library and Information Science Research as the Social Construction Process. (pp. 271-290) Emerald Group Publishing Limited.

McKiernan, E.C. et al. 2016. How open science helps researchers succeed. eLife, 5: e16800.

Nashihuddin, W. 2014. Perkembangan pendidikan ilmu perpustakaan Indonesia: dari masa ke masa. Jurnal Pustakawan Indonesia, 13 (1): 41-52.

Nashihuddin, W. \& Aulianto, D.R. 2016. Pengelolaan terbitan berkala ilmiah sesuai ketentuan akreditasi: upaya menuju jurnal terakreditasi dan bereputasi internasional. Jurnal Pustakawan Indonesia, 15(12): 83-98.

Prasetyawan, Y.Y. 2017. Perkembangan Open Access dan Kontribusinya bagi Komunikasi IImiah di Indonesia. Anuva, 1 (2): 93-100.

Purnomowati, S. 2001. Kondisi majalah Indonesia bidang ilmu perpustakaan dan informasi di awal abad 21. Baca, 26(1-2):27-31. 
J.Pari Vol. 4 No. 2 Desember 2018 : 